\title{
Dreams and Visions as Diagnosis in Medieval Sufism
}

\section{The Emergence of Kubrawi Oneirology}

\author{
Eyad Abuali \\ Utrecht University (The Netherlands) \\ e.abuali@uu.nl
}

\begin{abstract}
In recent scholarship the notion that dreams and visions in Islamic societies are phenomena with no relevance to historic events or societal concerns has been challenged and overturned. However, the theoretical underpinnings of Sufi oneirology in the medieval period have yet to receive a full exposition. Furthermore, the relevance of such seemingly abstract texts to Sufi organisational and institutional structures has not been realised. This article argues that understanding the development of Kubrawī oneirology offers important insights into Islamic thought and society. Focusing on the first generation of Kubrawī Sufi thinkers, this article accounts for the emergence of diagnostic oneirology in the sixth/twelfth and seventh/thirteenth centuries in two steps. Firstly, by detailing the systematisation of oneiric theory which occurs in early Kubrawī thought. And secondly, by demonstrating that this systematisation crafted a close relation between Sufi theory and the communal and institutional bonds that allowed the Sufi community to adapt to changing socio-political circumstances.
\end{abstract}

\section{Keywords}

dreams - Kubrawiyya - Majd al-Dīn al-Baghdādī - Najm al-Dīn Kubrā - oneirology psychology - Sufism - visions 
The value of dreams and visions in the Islamic tradition is asserted in the Qur'an as well as the sayings of the Prophet. In early Islamic societies, much significance was attached to the divinatory role of dreaming and works regarding dream interpretation appeared very early on. By the second/eighth century, Ibn Sīīn (d. 110/729) had compiled an extensive encyclopaedia of dream images in his Tafsìr al-ahlām. In addition, the caliph al-Ma'mūn requested that Hunayn ibn Isḥāq (d. 26o/873) translate Artemidorus' Oneirocritica into Arabic. ${ }^{1}$ As a form of divination, dreams and visions began to feature prominently in early historiographical works where they acted as narrative devices which predicted or foreshadowed the success or demise of a particular ruler. ${ }^{2}$ In earlier periods, the nature of oneirological works indicates that dreams were largely valued for this divinatory role. ${ }^{3}$ Yet, that there emerged a complex theory of diagnostic oneirology in medieval Sufism is not widely acknowledged.

In this article, I will account for the emergence of diagnostic oneirology in two steps. Firstly, by showing that systematic dream interpretation was made theoretically possible by the development of Kubrawi Sufi psychology in the sixth/ twelfth and seventh/thirteenth centuries. And secondly, by demonstrating that the diagnostic value of dream interpretation became more important as loosely structured Sufi communities began to centralise around the authority of a single shaykh. This trend would continue until communities eventually transitioned to Sufi orders with exclusive lineages stretching back to particular masters. ${ }^{4}$

One can point to examples of visionary autobiographies as early as the third/ninth century. Al-Hakīm al-Tirmidhī's (d. 279/892) Bada'sha'n for example is interspersed with accounts of the author's dreams and visions as well as those dreamt by his wife. Given the autobiographical nature of the text, the dreams do have a diagnostic quality about them, reflecting al-Tirmidhï's

1 Nile Green, "The Religious and Cultural Roles of Dreams and Visions in Islam," Royal Asiatic Society of Great Britain and Northern Ireland 13 (2003): 287-313.

2 Fahd Toufy, "The Dream in Medieval Islamic Society," In The Dream and Human Societies, ed. Gustav Von Grunebaum and Roger Callois, (Berkeley and Los Angeles: University of California Press, 1966), 359 .

3 Huda Lutfi, "The Construction of Gender Symbolismin in ibn Sīrīn's and ibn Shāhīn's Medieval Arabic Dream Texts," Mamluk Studies Review 9 (2005): 120-61, 124.

4 Erik Ohlander, Sufism in an Age of Transition: 'Umar al-Suhrawardī and the Rise of Mystical Brotherhoods, (Boston: Brill, 2008), 1-15; Jurgen Paul, Doctrine and Organisation: The Khwajagan Naqshbandiya in the First Generation after Bahäuddin (Berlin: Das Arabische Buch, 1998), 3; 75-7. 
spiritual development. ${ }^{5}$ However, these passages by no means present a systematic approach to the interpretation of dreams. ${ }^{6}$

This is in marked contrast to the texts I will discuss here which systematically uncover the meanings of some fantastical, and at times disturbing imagery. By employing the term "diagnosis" then, I mean to draw attention to the development of an approach to dream interpretation which attempted to accurately pinpoint the condition of the soul and its various faculties, or "organs." Diagnosing the psycho-spiritual condition of Sufis through dream interpretation in this way facilitated the centralisation of the community around the Sufi master by incorporating the individual's private spiritual-mental experiences into a theoretical framework which was collectively shared. In exploring this, I have chosen to analyse some of the least studied Kubrawi texts in order to highlight the value of these texts for the study of Sufism.

Huda Lutfi posits that dream texts in medieval Islamic societies had been undervalued by historians in the past because they seem to be unrelated to socio-historical events. ${ }^{7}$ Moreover, Hagar Kahana-Smilansky has shown that Muslim autobiographical dream texts in the medieval period were dismissed and treated as "stylised expressions of social conventions" that do not betray the author's genuine experiences or ethical considerations. ${ }^{8}$ Both authors do much to overturn such conceptions, Lutfi argues for the relevance of dreams to understanding medieval Islamic societies, while Kihana-Smilansky highlights the personal and autobiographical significance of dreams in medieval dream diaries, specifically with reference to conversion narratives and spiritual transformations.

We may also note that what seem to be highly personal dream narratives often tell us much about communal and institutional structures operating in medieval Islamic society. In this regard, Shahzad Bashir has highlighted the close relation between transformative visions and initiation into Sufi spiritual chains of lineage (silsila) in hagiographies concerning eighth/fourteenth and ninth/fifteenth century Persianate Sufi figures. This reveals a close connection between spiritual transformations induced by visions and communal bonds. ${ }^{9}$

5 Bernd Radtke and John O'Kane, The Concept of Sainthood in Early Islamic Mysticism, (Richmond: Curzon Press, 1996), 14-36.

6 Radtke and O'Kane, The Concept of Sainthood, 27.

7 Lutfi, "The Construction," 124.

8 Hagar Kahana-Smilansky, "Self Reflection and Conversion in Medieval Muslim Autobiographical Dreams", In Dreaming Across Boundaries, ed. Louise Marlow, (Cambridge Mass.: Harvard University Press, 2008), 99-101.

9 Shahzad Bashir, Sufi Bodies, (New York: Columbia University Press, 2011), 93-6. 
In exploring this interconnection between the personal and communal with respect to medieval oneirology, I draw on the work of Amira Mittermeier. Mittermaier's study of contemporary Egyptian dreaming cultures demonstrates that dream experiences, which are understood to be products of self-cultivation and prophetic insight, "enable modes of belonging that entirely exceed the visible"10 and "highlight the dreamer's embeddedness in larger realities and larger communities."11

Mittermaier's conclusions are helpful when considering the early Kubrawiyya. These authors produced rich articulations of oneirology which grant us insights into the personal dream and visionary experiences of medieval Sufis, as well as the way in which these experiences were contextualised within a shared theoretical framework. As such, despite their seemingly abstract explorations of cosmology and psychology, these texts are intimately connected to the social and communal expressions of Kubrawī Sufism in the sixth/twelfth and seventh/thirteenth centuries.

Some scholars have already grappled with the highly personal nature of medieval Sufi dream texts and what they may tell us of broader Sufi trends. Arin Salamah-Qudsi has highlighted a transition in Sufi autobiographical dream texts from a style that emphasised the narrative functions of dreams in order to directly address the collective concerns of the Sufi community, to a style which more intimately explores the individual experiences of the Sufi in the sixth/twelfth and seventh/thirteenth centuries. ${ }^{12}$ Salamah-Qudsi posits that the development of Suf theories regarding the nature of the soul as well as the increasing authority of the Sufi master in his community helped popularise this latter form of dream autobiography. ${ }^{13}$ These conclusions identify two of the most important factors which contributed to the increased production of diagnostic dream texts. However, there remains much to be done in demonstrating the theoretical and socio-historical developments which facilitated this shift.

Moreover, although there was indeed a more systematic and detailed emphasis on the individual's experiences in these later dream autobiographies, this was not irrelevant to the collective concerns of the Sufi community. Rather, such texts provide crucial opportunities to link Sufi theory to everyday practice, reinforcing the organisational structure of the Sufi community. As Mittermaier has observed, "by seeing, telling, and writing their visions, as

10 Amira Mittermaier, Dreams That Matter: Egyptian Landscapes of the Imagination, (London: University of California Press, 2011), 110-11.

11 Amira Mittermaier, Dreams That Matter, 233.

12 Arin Salamah-Qudsi, "The Will to be Unveiled: Sufi Autobiographies in Classical Sufism," Al-Masaq Journal of the Medieval Mediterranean 24 (2012): 199-207, 205.

13 Arin Salamah-Qudsi "The Will," 205-7. 
well as through reexperiencing them by way of the many retellings," Sufi adherents participate in "constructing and upholding" the Sufi master's authority. ${ }^{14}$ Although Mittermaier refers to contemporary Egypt, this largely holds truth with respect to the early Kubrawi texts considered here.

The Kubrawiyya trace their spiritual lineage back to Najm al-Dīn Kubrā (d. 617/1221), an influential Sufi master (shaykh) and writer. Some of the most important Sufi authors and practitioners from the sixth/twelfth and seventh/ thirteenth centuries trace their lineage back to him. Moreover, the early Kubrawis maintained close relations with the rulers of their time, from the reign of the Khwarazmshahs to the Mongol Ilkhanate, and remained an influential Sufi community for a number of centuries. ${ }^{15}$ This was a tumultuous period in the history of Iran and Central Asia. In such a violent and fractured socio-political climate, the proliferation of diagnostic dream texts in this period tells us much about the ways in which Sufis navigated such disruptions.

It is important to consider the early Kubrawiyya's oneiric theory in this respect since they have on occasion been mischaracterised as a reclusive, ascetic community due to this very emphasis on the interpretation of dreams and visions. ${ }^{16}$ While scholars have in the past highlighted the diagnostic nature of Kubrawī oneirology, its implications for Islamic thought and society more generally have not been fully grasped. ${ }^{17}$ As such, our understanding of the early Kubrawīs remains incomplete as long as their oneirology remains obscure.

\section{The Systematisation of Oneiric Theory: Najm al-Dīn Kubrā and Majd al-Dīn al-Baghdādī}

Understanding the psychological framework of the early Kubrawiyya which informs their oneiric theory depends on two steps. The first is grasping the anatomical make-up of the soul, identifying each "organ" of the soul with its psycho-spiritual function. The second is identifying the micro-cosmological scheme of Kubrawi thought which provides the interpretative framework that

\footnotetext{
14 Mittermaier, Dreams That Matter, 120.

15 Jamal Elias, "The Sufi Lords of Bahrabad: Sacd al-Dīn and Șadr al-Dīn Hamuwayi," Iranian Studies 27 (1994): 53-75, 67.

16 Devin Deweese, "The Eclipse of the Kubrawiyya: Sayyid 'Ali Hamadānī and Kubrawī Hagiographical traditions," In Studies on Sufism in Central Asia. Edited by Devin Deweese, (Farnham: Routledge, 2012), 79-8o.

17 For an example of a study discussing Kubrawī dream interpretation, see Jamal Elias, "A Kubrawī Treatise On Mystical Vision: The Risāla-yi Nūriyya of 'Alā' al-Dawla as-Simnānī," The Muslims World 83.1 (1993): 68-80, 69 .
} 
establishes a correspondence between certain images and the psycho-spiritual rank of the soul.

Some of the clearest expositions of Kubrawi psychological theory can be found in the work of Kubrā's student Majd al-Dīn al-Baghdādī's (d. 616/1219) Tuhfat al-barara fi al-masāil al-ashra, or The Gift of the Pious in the Ten Questions. Al-Baghdādī was one of Kubrā's most prominent students who issued licences ( $i j \bar{a} z a)$ to transmit and teach Sufism to some of the most influential Kubrawīs. His students include the well-known Sufi author Najm al-Dīn al-Rāzì (d. 654/1256) whose own work was heavily influenced by the Tuhfa, ${ }^{18}$ as well as Raḍī al-Dīn 'Alī Lālā (d. 642/1244) through whom the order came to trace its lineage to Kubrā. ${ }^{19}$ This text offers a more systematic account of Kubrawī oneiric theory than what we may find by reading Kubrā's work, the Fawäì al-jamāl wa fawātih al-jalāl, on its own. Analysing al-Baghdādī's thought grants an insight into the ways in which Kubrä's ideas were developed by the first generation of Kubrawi thinkers.

Al-Baghdādì's organisation of the soul's anatomy is very much influenced by Abū Ḥāmid al-Ghazālī (d. 505/1111). This is seen when al-Baghdādī explains that man is constructed from all the realities in existence. ${ }^{20}$ For al-Ghazālī, the soul receives knowledge of realities (haq $\left.\bar{a}^{\prime} i q\right)$ when they are imprinted onto the heart, which he describes as a mirror, according to the extent to which it is polished. As Treiger has shown, the term "realities" in al-Ghazālì's thought intends to replace the philosophical notion of intelligibles. In doing so, al-Ghazāli stresses that it is not the intelligibles themselves but their forms that are imprinted onto the heart. ${ }^{21}$

For al-Baghdādī, realities are presented to the heart as forms with sensory particulars and are not limited to abstract intelligibles. Al-Baghdādī also locates these realities within man as well as the external cosmos. In the Tuhfa, he divides all created things into either belonging to the hidden (ghayb) or manifest (shahäda) worlds. The human being's composition consists of all

18 See for example al-Rāzī's Manārāt al-sāiirin which borrows heavily from the Tuhfa. Al-Rāzī, Manārāt al-sā̉irinn wa-maqāmat al-țāirìn, ed. Sacid 'Abd al-Fattāḥ (Cairo and Kuwait: Dār Sacād al-Ṣabāḥ, 1993).

19 See Khirqa Hazārmīkhī, ed. Mohammed Danishpazuh in Collected Papers on Islamic Philosophy and Mysticism, ed. by Mehdi Mohaghegh and Hermann Landolt (Tehran: Tehran University Press, 1971).

$20 \quad$ Al-Baghdādī often quotes al-Ghazālī's 'Thyā' 'ulūm al-dīn and Mishkāt al-anwār, and was heavily influenced by both works. Al-Baghdādī, Tuhfat al-barara fì al-masā̉il al-'ashra, MS Süleymaniye, Karacelebizade 353, fols. $2 \mathrm{~b}-77 \mathrm{~b}$, fol. $8 \mathrm{~b}$.

21 Alexander Treiger, Inspired Knowledge in Islamic Thought: Al-Ghazäli’s Theory of Mystical Cognition and its Avicennan Foundation (Abingdon and New York: Routledge, 2012), 32-3. 
realities of both realms. This is explained as a consequence of man's composition of body and soul:

[God] created the human as constructed from all the realities of the hidden and manifest. And God has said: "And I fashioned him and breathed into him from my spirit [15:29]." So the 'fashioning' is from the manifest and the 'breathing in of the spirit' is from the hidden. So there is no thing in the manifest that is not within the human's manifest-ness. And there is no thing in the hidden that is not within the human's hiddenness. ${ }^{22}$

With regard to the body, man's frame is the most complex bodily composition in manifest creation which means that it shares its faculties with all other bodily existents. Likewise, the soul as the greatest creation in the hidden world, shares its nature with all hidden existents. Al-Baghdādī explains that this is because man is nearest to the presence of God with respect to the soul and furthest from that presence with respect to the body:

There is no thing in the world of bodies (ajsām) closer to the presence of Godliness than the Throne, because it is the place where the rule of mercy is bound. And from it the world of bodies arises, [first] the seven celestial spheres, and after them comes the ether (al-athir) and fire, then air, then water, then earth, then the things which are composed of these elements which are the species of minerals, plants and animals. So, if you consider all the existents, you find that the furthest from the presence [of Godliness] in reality is the world of bodies. And if you consider the world of bodies as varieties of constructions from the different elements, of which the form of man's bodily frame is [one such thing]... Then, the image of [man's] physical form is the furthest of compositions from the presence [of Godliness] and he is in truth the lowest of the low. ${ }^{23}$

For al-Baghdādī, the emphasis of this process of creation is placed on the progression of existents from material simplicity to complexity. God's essence first emanates onto the cosmological throne which lies between the hidden and manifest. God then commands the manifest world through the throne. Next in bodily complexity to the throne are the seven heavenly spheres. On the sphere of earth, the four elements combine to create bodies. The natural state of the elements is to remain separate, however they can be forced to unite in order to

22 Al-Baghdādī, Tuhfat al-barara, fol. 8b.

23 Al-Baghdādī, Tuhfat al-barara, fol. ga-9b. 
produce more complex bodies. In certain philosophical schemes the elements may combine and behave against their nature in order to produce a body when conditioned by some force such as a soul or an intellect. ${ }^{24}$ Hence, the increase in compositional complexity indicates further removal from the natural state of the elements. Bodies are composed of a combination of these elements, and the more complex they are, the further removed they are from their natural state. In order of increasing complexity these are, inanimate objects, plants, animals and finally humans. Man is therefore the most complex existent possessing human, animal, vegetative and mineral faculties. This reflection of the macrocosm within the microcosmic composition of man establishes that every perceptible reality external to the human being corresponds to a reality within his or her own composition.

Al-Baghdādì's understanding of man as a microcosm also explains the relationship between the body and the soul, which mimics the relationship between God and the cosmos. What I mean by the term 'soul' here is that nonbodily substance in its entirety which is described as the counterpart to the body. In the Tuhfa the soul is subdivided into faculties which account for its various functions and psycho-spiritual ranks. Here al-Baghdādī presents us with four faculties of the human soul: the lower soul (nafs), spirit (rüh), heart (qalb) and innermost heart (sirr).

The technical usage of nafs in Kubrawi thought refers to what shall be translated here as lower soul. ${ }^{25}$ This is because the term in the Tuhfa refers to a soul which is dominated by its desire for material gain, pleasure or comfort and must be tamed and disciplined like a riding animal. ${ }^{26}$ It is subdivided into a commanding lower soul (which commands the person to sin), a blaming lower soul (which regrets its sins) and a pacified lower soul. The latter state is often described by al-Baghdādì as the beginning stages of the heart, and indeed the pacified lower soul is described as turning into a heart in the Tuhfa. ${ }^{27}$

The spirit represents man's loftier nature and causes him to express praiseworthy attributes as it is associated with worship ('ubüdīya). Hence there is a tripartite conception of the soul's three general ranks of lower soul, heart

24 Sarah Strouma and Sara Sviri, "The Beginnings of Mystical Philosophy in al-Andalus: Ibn Mașarra and his Epistle on Contemplation," Jerusalem Studies in Arabic and Islam 36 (2009): 201-53, 205; Jon McGinnis, Avicenna, (Oxford and New York: Oxford University Press, 2010), 88.

25 The term nafs can be used to refer to the soul or the self in its entirety, as al-Baghdādi does on occasion. Al-Baghdādī, Tuhfat al-barara, fol. 8a-9b.

26 Annemarie Schimmel, Mystical Dimensions of Islam (Chapel Hill: University of North Carolina Press, 1975), 112-13.

27 Al-Baghdādī, Tuhfat al-barara, fol. 4a. 
and spirit. ${ }^{28}$ For al-Baghdādī, the dominance of the spirit over man's being is often associated with the love of the hidden and immaterial (ghayb), desiring worship, ecstatic states, seclusion and visions. In the Tuhfa, the spirit may also perceive hidden truths or future events as a type of spiritual sensory organ. ${ }^{29}$

With regard to the heart (qalb) and innermost heart (sirr), their functions are specified as spiritual organs which command the body. In explaining the role of the heart and the innermost heart al-Baghdādì uses a cosmological allegory to liken the heart to the cosmological throne of God ('arsh) and the innermost heart to his seat (kursì):

Just as God has created ... an intermediary between the hidden and manifest, which is the throne, so has he created for man [an intermediary] between his manifest-ness and hiddenness which is the heart ... And just as God created for himself a seat above the throne, so too did he create for man a seat above the heart which is the innermost heart. ${ }^{30}$

Al-Baghdādī then explains that the cosmological seat (kursī $)$ is the locus of divinity (ulühiyya) while the cosmological throne is the locus of mercifulness (rahmāniyya). ${ }^{31}$ This refers to a distinction between essence and attribute, which was common in Islamic cosmology, that identifies the innermost heart as man's essence that emanates unto the heart which acts as the locus of man's attributes. ${ }^{32}$ The heart then commands the body in accordance with the essence, just as the cosmological seat represents the essence of God which emanates onto the throne, through which God commands the physical world. In the microcosm of man, the innermost heart's emanation onto the heart and its subsequent command of the body results in the bodily expression of attributes (sifät). The heart can be dominated by the lower soul, the spirit, or God, causing the body to express attributes that correspond with each psychospiritual condition accordingly.

The heart is therefore described both as that spiritual organ which commands the body, as well as that which perceives realities. Collapsing both functions

28 Schimmel, Mystical Dimensions, 191.

29 At times the term rüh, like nafs is also used to refer to the soul or self in the Tuhfa. Therefore, when these terms are encountered in their more general sense, I will translate rūh as 'soul' and nafs as 'self'.

30 Al-Baghdādī, Tuhfat al-barara, fol. 8b-9a.

31 Al-Baghdādī, Tuhfat al-barara, fol. 8b-9a.

32 Timothy Gianotti, Al-Ghazālı̀s Unspeakable Doctrine of the Soul: Unveiling the Esoteric Psychology and Eschatology of the Ihya $\vec{a}$ (Leiden: Brill, 2001), 74. 
of perception and command of the body into the single spiritual organ of the heart is an important step towards asserting the diagnostic value of dreams and visions. It establishes an intimate correspondence between the images presented in visions on one hand, and the rank of the soul and its expression of attributes through the body on the other. Moreover, by shifting the emphasis onto realities within one's own composition, al-Baghdādī's Sufi is primarily perceiving realities which are contained within him.

This interiorisation of realities is made more apparent when al-Baghdādī expands on al-Ghazāli's metaphor of the heart as a mirror found in the Mishkāt al-anwār. ${ }^{33}$ Al-Baghdādī explains that in addition to "polishing" the mirror of the heart from blemishes, it must also be properly aligned with a "source of light" in order to perceive the realities which al-Baghdādī firmly locates within one's own existence (wujūd). ${ }^{34}$ The extent to which an image may be imprinted in the mirror of the heart then depends on the alignment and polishing of the mirror so that it may reflect light onto an object and subsequently receive the imprint of its image. Perceiving one's inner realities then depends on the purification and correct orientation of the heart, furthering the case for the diagnostic value of perception.

An example of the correspondence between images and psycho-spiritual progression is seen when al-Baghdādī maps the visionary experiences of the Sufi onto the micro-cosmological understanding of man's composition. In the Tuhfa, al-Baghdādi describes the progression of visions as a literal inversion of the sequence of creation, sketching an ascent from complexity to simplicity and towards God. The progression of images is described in the following passage where al-Baghdādī details the visionary journey of the Sufi:

[The seeker] sees the things which are stored within him, and he passes over them and traverses them ... And [first] he sees the realities of earthly things in the order of different types of animals, then plants then inanimate things when the attributes of animalness and other [attributes] are revealed to him. Then his wayfaring continues to the elements until he reaches the ether of his inner being which is the culmination of the attributes of the lower soul. And he sees the realities of the attributes of the lower soul sometimes ... in the image of ugly sensible things ... and at

Abū al-Ḥāmid al-Ghazālī, Mishkāt al-anwār, ed. Abū al-'Alā' al-'Afïfī (Cairo: al-Dār al-qawmiyya li-l-țibā‘a wa-al-nashr, 1964) 53-4.

34 Al-Baghdādī, Tuhfat al-barara, fol. 59a. The term wujūd in Kubrawī texts refers to existence as a condition. See, Cyrus Ali Zargar, "The Ten Principles: Theoretical Implications of Volitional Death in Najm al-Dīn Kubrā’s al-Ușūl al-'ashra (A Study and Translation)," The Muslim World 103 (2013): 107-30, 120. 
times in the images of enemies, [such as] snakes or scorpions ... And the wayfarer at this point in his journey is between two perspectives: One looking to what is within him, and one looking to what is above him. And if he looks to what is within him he sees the realities of earthly things, and if he looks to what is above him he sees the celestial and heavenly spheres. $^{35}$

Here, al-Baghdādī presents the visionary ascent of the individual as an inversion of cosmic sequence of creation. According to the microcosmic understanding of the human being, the visionary journey consists of perceiving the realities of the hidden and manifest which are contained within one's own composition. The initiate begins his journey in a state dominated by the most complex bodily existent, and this is symbolised in his visions. As he progresses along the path of Sufi discipline, these images move from material complexity to simplicity until he begins to see the celestial bodies which indicate the higher faculties of the soul. At one point in the text al-Baghdādi equates the celestial bodies with the heart directly as he says, "the seeker witnesses the planets of the heart" (yushāhid kawākib al-qalb). Since he has not yet "passed over" the celestial bodies but perceives them above him, al-Baghdādì's visionary traveller here stops between the ranks of the pacified lower soul which is represented by the ether, and the heart which is represented by the celestial spheres. ${ }^{36}$ Hence, while the descent of man occurs in the macrocosm, the ascent occurs through the microcosm.

Visions also bear a relationship to micro-cosmology and the rank of the soul in Kubrā's Fawäih. For example, in detailing the difference between visions of the lower soul and the devil Kubrā describes the following visions:

Existence $(w u j \bar{u} d)$ is an intense darkness at first, and if it is purified a little it takes the form of a black cloud. And if it is the throne of Satan it is red. And if it is corrected and the particulars ( $h u z \bar{u} z)$ are removed from it, and the truths remain, it is purified and is whitened like cirrus. And the lower soul, when it begins [to manifest], its colour is the colour of the sky which is blue ... And the lower soul emanates upon existence and fashions it. And if it is purified and made good, it emanates onto it goodness,

35 Al-Baghdādī, Tuhfat al-barara, fol. 10a-1ob.

36 Al-Baghdādī, Tuhffat al-barara, fol. $10 b$. 
and goodness grows from it. And if it emanates onto it evil, then just the same, evil grows from it. ${ }^{37}$

We may note similarities between al-Baghdādī's and Kubrā’s interpretative method here. When the lower faculties of the soul are dominant over the psyche, the vision is dark and dense just as the complex bodies are further removed from the presence of God. When these faculties are overcome, the visions become lighter in tone and colour just as the higher faculties of the soul are simpler and closer to God. Here, Kubrā clearly links vision to the expression of attributes in accordance with the Tuhfa. Because the expression of attributes through the body is tied to perception here, the diagnostic value of the image is established. This is the basis for the concordance between visions and wujūd in Kubrāss passage above.

\section{Thought Impressions and the Inner Senses}

Having established the cosmological basis for Kubrawi psychological theory, al-Baghdādī turns to the mechanism through which dreams and visions are produced, outlining the relationship between thought impressions (khawattir), the inner senses, and the soul. The sources of thought impressions mentioned here are the lower soul, the devil, angels, the heart, the spirit, the Sufi master and divine inspiration (ilhäm). ${ }^{38}$

For al-Baghdādī thought impressions determine the nature of the images one receives in sleep or in states between sleep and wakefulness. The clarity of the images produced by thought impressions parallels the Sufi's progress along the path. Al-Baghdādī explains that as the soul advances in purification, so too does its understanding of thought impressions. ${ }^{39}$ In the Tuhfa, thought impressions act as a veil to divine inspiration. ${ }^{40}$ In other words, divine inspiration is constantly distorted by thought impressions and only occurs clearly with their negation. In order to receive unadulterated divine inspiration, al-Baghdādī states that the Sufi should enter seclusion (where a state of sensory deprivation is prescribed) and perform recollection (dhikr). He stresses that in seclusion

37 Najm al-Dīn Kubrā, Fawā̉ih al-jamāl wa-fawātiḥ al-Jalāl, ed. Youssef Zeidan, (Kuwait: Dār Sac̄ā al-Ṣabāh, 1993), 125-6. I use Zeidan's edition here since it takes Fritz Meier's edition of the Fawāih into account, and compares it against additional manuscripts. See Zeidan, Fawä̉ih, 113-14.

38 Al-Baghdādī, Tuhfat al-barara, fol. 39b.

39 Al-Baghdādī, Tuhfat al-barara, fol. 41a-41b.

40 Al-Baghdādī, Tuhfat al-barara, fol. 39b. 
the disciple should negate the reception of thought impressions by repeating the profession of faith, "lā illaha illā Allāh."

This understanding of thought impressions is integral to the phenomena of dreams and visions. Al-Baghdādī explains that dreams and visions are produced in conjunction with thought impressions. He states that, just as man has five outer senses, so too does he have five inner senses located in the brain (dimāgh). In this passage, he mentions Avicenna's five inner senses. These are the common sense (al-hiss al-mushtarak), which gathers the sensory data from physical senses, the imaginal store (al-khayāl) which stores the sensory data, estimation (al-wahm) which gathers the meanings of sensory data, and the store of these meanings is termed al-dhäkira. Most important here is the imaginative faculty (al-mutakhayyila) which is able to combine and reproduce different images and meanings and project them onto the perceiver's mental screen.

Al-Baghdādī then explains that during sleep, or in a state which he describes as between wakefulness and sleep (ghayba) induced through the practice of recollection, the imaginative faculty is "strengthened" and "speaks" of whatever is dominant over the person's inner being (bäțin) by means of the images of sensible things which have been stored in the mind. ${ }^{41}$ The thoughts that are impressed upon the soul in these states are determined by whichever faculty predominates over the soul at that given moment. The imaginative faculty then combines the sense data gathered in waking life into a symbolic representation of the thought impression.

This draws on the Avicennan understanding of the function of the inner senses. For Avicenna, in the event of physical sensation, the perception is transferred from the sensory organ via the pneuma to the nerves, this is then sent to the common sense, followed by the imaginal store. Here, the outer senses always function in conjunction with the inner senses. Hence, while the outer senses perceive the world, the inner senses are constantly called upon to make sense of it so that the intellect may abstract truths from these perceptions. ${ }^{42}$ However, when the outer senses cease to function, the imaginative faculty is free to combine images and meanings and present them to the mind. Al-Baghdādī relies on this conception of the inner senses in his account of dreams as he explains that during sleep, the imaginative faculty is

41 Al-Baghdādī, Tuhfat al-barara, fol. 41b.

42 Dag Nikolaus Hasse, Avicenna's De Anima in the Latin West: A Peripatetic Philosophy of the Soul 1160-1300 (London: The Warburg Institute, 2000), 121-2; 138. 
strengthened and "clothes" each thought impression that the soul receives with a sensible image which carries a meaning appropriate to it. ${ }^{43}$

The ability of the inner senses to represent appropriately these spiritual truths through images remains deficient so long as the baser thought impressions distort them. With Sufi practice these thoughts are negated and a veridical dream emerges (ru'ya șādiqa). ${ }^{44}$ There is a close connection here between the practice of recollection and visions. Recollection functions as a method for inducing these higher visions within the practitioner by negating the outer senses and thought impressions, while allowing one to enter a state between sleep and wakefulness where the Sufi is more receptive to spiritual visions. ${ }^{45}$

The full progression of visions is then presented by al-Baghdādī in symbiosis with the spiritual progression of the individual. In each stage, the imagination is aligned with the soul and the visions become clearer and more comprehensible as the soul is progressively purified. Like the heart, the imagination is always ruled by a specific spiritual faculty. In the ranks of the lower soul and the spirit, dreams require interpretation by a Sufi master. However, when God takes command of the imagination upon spiritual completion, visions convey direct truths which are immediately understood and have no need for interpretation. ${ }^{46}$

This scheme is repeated in Najm al-Dīn al-Rāzī’s (d.654/1256) Mirșād al-'ibād in a more abbreviated form with reference to Qur'anic parables. Al-Rāzī likens the unclear dream to that perceived by the king who imprisoned Joseph, the dream in the state of the spirit is that which Joseph himself experienced when beholding the stars, and the true literal vision is equated with Abraham's dream where he is told to sacrifice his son, explaining that it had no need of interpretation. ${ }^{47} \mathrm{Al}$-Rāzì's entire chapter on visions in the Mirșād is heavily indebted to al-Baghdādì's Tuhfa. Clear parallels with al-Baghdādī's cosmology are seen in his detailing of visions, and much of al-Baghdādì's discussion is repeated here. ${ }^{48}$

43 Al-Baghdādī, Tuhfat al-barara, fol. 42a.

44 Al-Baghdādī, Tuhfat al-barara, fol. 42a.

45 Al-Baghdādī, Tuhfat al-barara, fol. 45a.

46 Al-Baghdādī states: [God] renders [the imagination] an intermediary between the hidden and the manifest, so that the servant perceives with [the imagination] the realities of the hidden. And as long as it is subjected to the governance of the spirit, the disciple requires the master in order to know the truth of his witnessings. And if the governance of God takes possession [of it], he no longer requires a teacher other than Him, so just as He shows him a vision, He inspires him with its reality. Al-Baghdādī, Tuhfat al-barara, fol. 45a.

47 Najm al-Dīn al-Rāzī, Mirșād al-'ibād min al-mabda' ilā al-ma'ād, trans. Hamid Algar (Delmar, New York: Caravan, 1982), 287-8.

48 Al-Rāzī, Mirșād, 287-8. 
The psychological framework constructed by al-Baghdādīs microcosmology in conjunction with the functions of inner sensation and thought impressions expands, in a more systematic manner, upon Kubrās interpretations of dreams and visions. It builds upon Kubrā's statements which identify a correspondence between the spiritual faculties of the human being, the cosmos, and the images Perceived by the Sufi such as the following:

Know that the lower soul, the devil, and the angel are not things external to you (laysat ashyā'khärijatan 'anka), but you are them (bal anta humm). Likewise [the celestial] heaven, earth and the seat [of God] (al-kursī)... They are but things within you (innamā hiya ashyä' fika), and if you travel spiritually and become purified, you will see that clearly, God willing. ${ }^{49}$

These correspondences are systematised into a more intricate psychological framework by al-Baghdādī, and are then incorporated into discussions of prophetology by al-Rāzī. These developments in early Kubrawī Sufism prefigure the far-reaching systematic integration of the spiritual faculties, which came to be known as subtle centres (lațäif), along with prophetology, cosmology and visions in the work of later Kubrawī authors such as 'Alā' al-Dawla al-Simnānī (d. 736/1336). ${ }^{50}$ As Toby Mayer notes, al-Simnānī's system of subtle centres is "inexhaustible in scope", synthesising a host of correspondences between different phenomena including physiology, visions, the occult, and cosmology. ${ }^{51} \mathrm{~A}$ full comparative study between this prolific thinker and the early Kubrawīs is therefore beyond the scope of this article. We may nevertheless highlight some aspects of al-Simnānī's thought that drew inspiration from these earlier Kubrawī works.

Notably, al-Simnānīs thought reveals a greater emphasis on the interiorisation of cosmology within the human being, hence each subtle centre corresponds to the cosmological existent from which it emanates, such as God's throne or the intellect. The dominance of a particular subtle centre (the number of which is expanded from the four mentioned in the earliest Kubrawi texts, to seven) over one's being also results in the manifestation of certain spiritual states, each of which is equated to the spiritual state of a particular prophet, and so each person has an "inner" prophetic state corresponding

49 Kubrā, Fawǟị, 171.

50 Jamal Elias, The Throne Carrier of God: The Life and Thought of 'Alä' al-Dawla al-Simnānī (Albany: SUNY, 1995), 81-4.

$5^{1}$ Toby Mayer, "Yogic-Ṣūfì Homologies: The Case of the "Six Principles" Yoga of Nāropa and the Kubrawiyya," The Muslim World 100 (2010): 268-97, 279. 
to the rank of the soul. ${ }^{52}$ This more elaborate and stratified system of correspondences and interiorisations was later incorporated into the teaching methodologies of Naqshabandī Sufi masters. ${ }^{53}$ It also therefore coincided with the increasing institutionalisation of Sufism which gained pace in the Ilkhanid and Timurid periods with more centralised organisational structures and an increased emphasis on distinct spiritual chains of authority. ${ }^{54}$

The early Kubrawīs were likewise actively involved in guiding a transition in the organisational structures of the Sufi community in their own time prefiguring these later developments in Sufism. Hence, the diagnostic significance of early Kubrawi oneirology which emerges in this period marked an important development in Sufi thought which influenced theory and practice for centuries to come. Kubrawī oneirology, with its system of correspondences between the rank of the soul, the conditions of its spiritual organs, cosmology, and visions was key to this. In order to realise the importance of these theoretical developments for the lived experiences of Sufis in the sixth/twelfth and seventh/thirteenth centuries, I now turn to examples where dream interpretation acts as a means for diagnosing psycho-spiritual conditions in Sufi practice.

\section{$4 \quad$ Dream Interpretation in Practice}

The mechanics of diagnostic dream interpretation are revealed in a series of dream narratives recounted in the Persian letters exchanged between al-Baghdādī and a certain Sharaf al-Dīn al-Balkhī. This text consists of al-Balkhī's dream narratives followed by al-Baghdādì's interpretations, and is found in a collective manuscript of short Sufi treatises and biographical works. Here, al-Baghdādī as al-Balkhī's Sufi master and instructor, takes the role of dream interpreter. The dream narratives and their interpretations are very much in accordance with the Kubrawī oneiric scheme sketched above. ${ }^{55}$

52 Al-Baghdādī had also equated prophets with different spiritual organs, yet instead of the seven-fold scheme al-Baghdādī betrays a less elaborate system than what we find in al-Simnānī, with Moses, Jesus and Muhammad corresponding to the states of the lower soul, the spirit, and the perfected soul, respectively. Moreover, al-Baghdādī made no mention of "inner" prophetic states, though this could be seen to be implied. See al-Baghdādī, Tuhfat al-barara, fol. 6 oa.

53 Mayer, "Yogic-Ṣūfì Homologies," 279.

54 Jurgen Paul, Doctrine and Organisation, 3.

55 Fritz Meier has already produced a transcription and paraphrase of the text. Here I provide another brief paraphrase of the two visions which I will discuss in order to highlight what is relevant to this study. I rely on Meier's notes in some places as parts of the manuscript have been damaged and rendered illegible. See Fritz Meier, 
Recounting the second in his series of visions, al-Balkhī informs al-Baghdādī that during seclusion he had witnessed a desert, empty apart from a well or pit. At first, he hears jarring sounds emanating from the well, followed by dark, heavy smoke and vapours. Animals then emerge from the well and begin transforming back and forth between animals and humans "in the blink of an eye" before killing one another. Then a giant serpent emerges from the well and swallows all the animals, but after a while regurgitates them back out again. Al-Balkhi explains that he became very frightened at this vision. He then hears a voice instructing: "grasp it and do not fear" [Qur'an 20:21]. He reaches out to grasp the snake but it eludes him and retreats into the well. Al-Balkhi then describes how his sense of physical sight returned to him and he perceived a ceiling and walls around him, indicating that he has awoken from the vision. ${ }^{56}$

Al-Baghdādī interprets this dream according to his psychological framework. He explains to al-Balkhi that the reason for the manifestation of these images in this manner is that the workings of the lower soul, sense perception, and the imaginative faculty had become dominant over al-Balkhi's inner being. Al-Baghdādī then tells us that the desert represents al-Balkhī's existence (wujüd) while the well represents his heart as the connection between the manifest and hidden (the body and soul). The animals represent the attributes of the lower soul, while the giant serpent represents al-Balkhi's spiritual progress. Al-Baghdādi explains that by taking up the cause of "desiring God", one's blameworthy attributes can be overcome. Accordingly, the serpent attempts to subdue the attributes of the lower soul but tires and must release them, indicating a spiritual fatigue. Al-Baghdādī notes that the voice al-Balkhī heard was a command from God quoting God's instruction to Moses to grasp the snake in the Qur'an [20:21]. The significance of the snake, as that which subdues the blameworthy characteristics is derived from the role of the snake in the Qur'anic Moses narrative whereby the true snake of Moses consumes the false, magical snake of pharaoh's sorcerers. ${ }^{57}$

In this case, al-Baghdādì maps the symbols of the dream onto the psychological and micro-cosmological framework outlined above. First al-Baghdādī makes sure to contextualises the psycho-spiritual state of the dreamer within

"An Exchange of Letters between Sharaf al-Dīn al-Balkhī and Majd al-Dīn al-Baghdādī," trans. John O'Kane in Essays on Islamic Piety and Mysticism, ed. Ulrich Haarmann and Wadad Kadi, (Leiden and Boston: Brill, 1999).

56 Majd al-Dīn al-Baghdādī and Sharaf al-Dīn al-Balkhī, MS Süleymaniye, Risāla ilā Majd al-Dìn al-Baghdādī, Fazilahmedpasha 1589 fol. 418b-421a, fol. 419b. See also, Al-Balkhī, "An Exchange of Letters," 275 .

57 Al-Baghdādī, Risāla, fol. 420a; Al-Baghdādī, "An Exchange of Letters," 275. 
the hierarchy of the soul's potential ranks of perfection, explaining to him the role of the senses and the imagination in his current condition. When he turns to interpreting the symbols of the dream, the concordance between oneirology and psychology is realised. It allows for the anatomy of the soul to be visualised by the perceiver. The heart as the connection between the hidden and manifest appears as a well or pit, while the animals and humans represent the psychospiritual condition of the lower soul (nafs). The giant serpent represents the desire of the soul to attain a loftier state and come closer to God, equating perhaps to the functions of the spirit $(r \bar{u} h)$. As each image corresponds to a distinct spiritual organ, together these images represent the entirety of the soul.

In another of al-Balkhi's visions, he describes how during the time of morning prayer and in a state of seclusion, his senses and all perceptible images (mușawwarāt) gradually slipped away from him and his sighthad "fallen" (sāqiț) from him. In between the darkness that ensued a single shining star began to flicker. At this point al-Balkhì tells us that he loses his sense of proprioception, not knowing up from down. After a while many beautiful shining stars appear. Eventually the moon manifests and erases the light of the stars while beautiful melancholic voices are heard, followed by voices praising God and reciting the profession of faith. Aromas of musk and amber then diffuse. At this point he feels his bodily and human form slip away from him, and is lost for words in his attempt to describe the experience. Suddenly an earthquake occurs; he hears the sound of thunder, and sees lightning. He then describes feeling his body turn to liquid and depart, leaving him in a condition of absolute abstraction and unaware of any notion of time. When an even greater light shines he describes his condition as one of perfect perception (idrāk-ikullī) and absolute consciousness. After the vision dissipates he describes his anguish, proclaiming that he wanted to throw himself down a well or beat himself, and that he blamed the practice of recollection, prayer and all creation for his misery. 58

In his interpretation, al-Baghdādi states that the darkness represents worldly concerns and attachments, but notes that al-Balkhī was made aware of this darkness, which indicates a dissociation from those same worldly concerns. ${ }^{59}$ The initial star signifies the hidden light beginning to emerge in the heart, cutting away the veil of darkness. ${ }^{60}$ The appearance of the moon indicates that the light has arrived to the heart which then transfers it to the limbs of the body. ${ }^{61}$ The appearance of stars represents the souls

$5^{8} \quad$ Al-Balkhī, Risāla, fol. 419b. Al-Balkhī, "An Exchange of Letters," 270-1.

59 For a fuller discussion of this concept see Meier, 'An Exchange of Letters', 253; 262-3.

6o As translated in Meier, "An Exchange of Letters," 253.

61 Al-Baghdādī, Risāla, fol. 42ob. Al-Baghdādī, 'An Exchange of Letters', 276. 
of the Suf masters while the moon represents the Prophet; together they help guide al-Balkhī to the presence of God. Al-Baghdādī explains that with the light of the heart, the true senses (hawāss-i haqiqgi $)$ are activated. ${ }^{62}$ As a result, al-Balkhī hears melodic voices and the recollection of the profession of faith. Al-Baghdādī states that according to this ability to perceive with the true senses, al-Balkhì beheld intoxicating aromas as a counterpart to the auditory experience of melodious recollection, and the visual perception of light. The final light represents God's manifestation but it is fleeting and does not last due to al-Balkhī's spiritual incompletion. Al-Baghdādī explains that al-Balkhī overcame egoistic and devilish thoughts, as well as his human attributes with the light of the heart, but was still under the influence of the rational faculty $\left({ }^{\prime} a q l\right)$. Therefore, this was not a permanent state. He explains that the effect of perceiving these lights of God's beauty, which are transient prior to psycho-spiritual completion, will result in longing, desire and sadness. ${ }^{63}$

Clearly, the interpretation of this vision also reflects the Kubrawi psychological framework. The lights represent al-Balkhi's attainment of a greater psycho-spiritual condition which is then transferred to the limbs of the body, representing the symbiotic relationship between visions and attributes. This interpretation also emerges as a counterpart to the previous vision within the text. While the previous vision represents the condition of a Sufi initiate, this vision represents that of an intermediate who falls short of completion. Taken together they constitute the obstacles which the Sufi must overcome throughout his journey to the presence of God. The initiate must overcome the workings of the lower soul, the body and the devil, while the intermediate is obstructed by the higher faculties of the soul.

This sketching of the Sufi path through visionary symbolism also raises the question of whether the sequence of dream narratives is consciously arranged in order to act as a visionary guide. The ordering of the visions seems intentional and indicates a change in the way Sufis came to write about dreams and visions. If writing these visions down was partly intended to provide a guide for mystical experiences, then it becomes apparent that texts like this mark a development in the genre of dream instruction that privilege the diagnostic aspect of dream interpretation in order to aid Sufi initiates. This also raises the question of whether the dreams recounted in these texts should be seen as

62 These true senses are discussed at length in the Tuhfa. They are described as the spirit of the five physical senses which corresponds to their form. They are perceived by the heart once the baser faculties of the soul are subdued. See al-Baghdādī, Tuhfat al-barara, fol. $67 \mathrm{a}-69 \mathrm{a}$.

63 Al-Baghdādī, Risāla, fol. 420a-42ob; Al-Baghdādī, "An Exchange of Letters," 276-7. 
spontaneous events that precede these interpretations, or whether disciples are in effect "trained" to dream according to the oneirological scheme sketched in Kubrawī thought. In my view, it seems that individual dream experiences both constitute, and are constituted by, these discussions of oneiric theory and practice. As Mittermaier notes, whenever a dream is told "it inserts itself into this-worldly social relationships and is shaped by them." ${ }^{64}$ Hence, dreams and visions act as occasions to reinforce theoretical and social structures, which in turn shape what is seen and how it is told.

Another of Kubrā's students, Sayf al-Dīn al-Bākharzī (d. 659/1261) provides us with further examples of diagnostic interpretations in his visionary autobiography Waqā̇ic al-khalwa, or The Visions of Seclusion. Al-Bākharzī was another of Kubrā's foremost disciples whose spiritual lineage survived for some time in Bihar and came to be known as the Firdawsiyya. ${ }^{65}$ The surviving manuscript is dated to 694/1295, placing it in close proximity to al-Bākharzī's lifetime. ${ }^{66}$ The text is similar to the exchange of letters between al-Baghdādī and al-Balkhī as it is comprised of al-Bākharzì's dream narratives followed by Kubrā's interpretations. Here, I will analyse just some of the dream interpretations found in this text.

One peculiar feature of Kubrawi oneirology which is emphasised by the title of this work is the increased usage of the term wāqia to refer to a vision. The term was certainly used in reference to visions before Kubrā's time. Kubrā's teacher 'Ammār al-Bidlīsī (d. 604/1207-8), in his Bahjat al-țāìfa, distinguishes between witnessing (mushāhada) and vision (wāqi'a) stating that witnessing arrives directly from God but visions occur through an intermediary. He explains that visions are beheld in a state prior to spiritual completion whereas witnessing occurs upon spiritual completion. As such visions come

64 Mittermaier, Dreams That Matter, 111.

65 Hamid Algar, "Sayf al-Dīn al-Bākharzī," in Encyclopaedia of Islam, Two, Brill Online, http:// brillonline.nl/.

66 Since I have not located further copies of the text as of yet, it will of course be necessary to treat it with some caution. However, given the clear consistency between the interpretative method in al-Bākharzī's text and what we have presented of Kubrā and al-Baghdādī so far, it is clear that this text shares the same oneirological theory and interpretive framework. Hence, we can say with some confidence that the Waqä ${ }^{\prime}{ }^{\top}$ is an early Kubrawī text which likely dates back to the first generation of Najm al-Dīn Kubrā's students. See Jan Just Witkam, Inventories of The Oriental Manuscripts of The Library of The University of Leiden (Leidein: Jan Just Witkam and Ter Lugt Press, 2006), 440. 
in various degrees of truth. At first, they may be influenced by the imagination and require interpretation as the "eye" of the heart begins to open. Upon spiritual completion they may become clearer so that visions give way to true witnessing. ${ }^{67}$ This understanding of the term is very similar to that found in al-Baghdādī's writings. ${ }^{68}$ One explanation for the increased usage of the term then is the systematisation of oneirology. Here, the true visions of witnessing (mushāhada) had to be distinguished from the more symbolic visions of the wāqi'a. Likewise, these visions are distinguished from dreams in that they occur in states between sleep and wakefulness as al-Baghdādī described.

The term wäqia is also closely associated with eschatological passages of judgement day and the resurrection in the Qur'an. The link between eschatology and visions may provide some clues as to the increased usage of the term in Kubrawī circles. In this period, the notion that the imagination would play a significant eschatological role began to circulate more widely. That souls were to experience the afterlife through the imagination rather than a physical human body seems to have been articulated by Avicenna and al-Ghazāli. Underpinning this was a notion of body-soul dualism which meant that after death, the soul would be attached to a new body in the afterlife in order to experience it through imagination rather than being resurrected in the same human body. ${ }^{69}$

As mentioned earlier, Kubrawī thought was heavily influenced by al-Ghazālī. That the dualistic account of body and soul found its way into Kubrawi thought is evident in al-Baghdādī's micro-cosmological scheme that starkly distinguishes between the creation of the materially complex body and the simple substance of the soul which does not take part in the process of creation. Furthermore, Kubrā's al-Ușül al-'ashra, or The Ten Principles, also indicates an acceptance of body-soul dualism. Kubrā explains that each of these principles is intended to help the Sufi undergo a "death before death." This was in order to detach the soul from its bodily concerns prior to the physical death so that the soul will not suffer upon its forced detachment from the body. ${ }^{70}$ The subsistence of the soul without the body upon death is an important premise which underpins the entirety of the work.

Some of the practices which facilitated the soul's attempts to undergo this death before death are closely associated with dreams and visions. In another of Kubrā's treatises, he states that the practice of recollection leads

\footnotetext{
67 'Ammār Al-Bidlīis̄i, Bahjat al-țāilfa, ed. Edward Badeen (Stuttgart: Steiner, 1999), 73-5.

68 See Al-Baghdādī, Tuhfat al-barara and Meier, "An Exchange of Letters."

69 Treiger, Inspired Knowledge, 92-3.

70 Zargar, "The Ten Principles," 123-4.
} 
to the experiences of death (sakarät al-mawt), which he describes as visions that those who are conscious, or "alive" (al-hạdirün) do not see. ${ }^{71}$ As discussed above, al-Baghdādī provides a psychological explanation for this as recollection produces the conditions necessary for the inducement of visions. These visions in turn have transformative effects upon the perceiver, shedding blameworthy attributes for more praiseworthy ones. Hence, the term wāqia may refer to an association with this pseudo death and resurrection, effecting a reconstitution of the soul. In this way, visions indicate the movement of the soul from one state to the other. This connection between the transformative effect of visions and eschatology is also further strengthened in al-Simnānī's Risāla-ī Nūriyya. ${ }^{72}$ The increased usage of the term by Kubrawīs then indicates the close association of visions with psycho-spiritual progression.

I will now paraphrase two of al-Bākharzì's visions followed by their interpretations: Al-Bākharzī begins recounting a vision he had witnessed while performing recollection. He explains that this recollection was then transported to his heart, at which point it was as if a door had opened onto the chamber of seclusion in which he was sitting. Through this portal he perceives the sky filled with bright stars and planets. He then describes the brightness of the stars and the shimmering of the planets overpowering his sight. He describes this as a moment in which his "chest was expanded", and as a time of bliss. He states that he remained observing this vision and returned to performing recollection more intensely until it was time to perform the dawn prayer. As he returned to the chamber of seclusion the sun began to rise. This seems to refer to the physical sunrise rather than a visionary one. He then praises God for this vision despite the fact that his eyes were closed and the chamber was dark. ${ }^{73}$

Al-Bākharzī then narrates a further vision. He describes a being with the body of a man and the head of a bird appearing before him. He then hears a voice informing him that this is the commanding lower soul (al-nafs al-amāra). Al-Bākharzī motivates himself to seize this opportunity and so he grasps a blade with which he decapitates it. At this point, a round wooden surface appears before him which he describes as "spinning like a water wheel" (tadūr $k a^{3} a n n a h a ̈$ falak al-düläb). It spins quickly and upon it are vessels of water $(k \bar{\imath} z \bar{a} n)$ and heads which are identical to the head of the commanding lower

71 Najm al-Dīn Kubrā, al-Khă’if al-hă’im min lawmat al-lā̉im, MS State Library of Berlin (Berlin), Wetzstein 2. 1704, fols. 107a-112b, fol. 108b-109a.

72 See 'Alā’ al-Dawla al-Simnānī's Risāla-ī Nūriyya which discusses the transformative effects of visions beheld by the Sufi while drawing on Qur'anic descriptions of judgement day. Elias, "A Kubrawī Treatise," 74; 76-9.

73 Sayf al-Dīn al-Bākharzī, Waqā’ial-khalwa, MS University of Leiden Library (Leiden), Or. 989 , fols. $77 \mathrm{a}-81 \mathrm{~b}$. 
soul which he had decapitated. It then speaks saying, "I am the lower soul and these heads are mine, whosoever cuts one of them [off], another takes its place, just as when water is poured out of a vessel of [those vessels attached to] a water wheel, another [vessel] is filled." When the vision subsides al-Bākharzi tells us that he was thrown into a long-lasting confusion. ${ }^{74}$

The first vision is interpreted by Kubră ${ }^{-75}$ as the opening of al-Bākharzì's "eye of the heart" (infataha 'ayn al-qalb) to the presence of Godliness. He explains that the sky he perceived abounded with the hearts of the intimates of God (awliy $\left.\bar{a}^{\prime}\right)$. He then refers to the Qur'an [67:16] as the basis of this interpretation. He equates the sky with God's throne and explains that it is a mirror to his dominion (malakütahu), and for this reason every soul is made visible as a star to a degree of brightness determined by the purity of that soul, and the extent to which it has done good (making it brighter) or sinned (making it dimmer). Kubrā then provides further evidence from the Qur'an and the prophetic tradition before proceeding to explain that since the Qur'an is contained within people's hearts and since these hearts are the stars themselves, the appearance of the stars also represents the Qur'an. ${ }^{76}$ He then states that beholding the sun indicates that one has been transported to the station of certainty and knowledge (maqām al-yaqin wa al-márifa). ${ }^{77}$

Regarding the interpretation of the second vision, Kubrā begins by stating that the blade is the blade of recollection. The round wooden surface with multiple bird heads upon it represents the lower soul. The multiplicity of heads represents the multiplicity of the lower soul's blameworthy attributes. He then explains that the commanding lower soul appears as a wooden surface because God has described the hypocrites in the Qur'an as such [Qur'an 63:4]. He explains that the wooden surface of the commanding lower soul is a veil to the heart which lies behind it, stating that spiritual exercise is required in order to overcome the lower soul and lift this veil. This will allow the power of the inner eye which he terms the "hidden sun" to be realised (quwwat al-ayn alladhì tuqāl lahā shams al-ghayb), hence the roundness of the wood is understood to obscure this round sun which is identified as the "eye" of the heart. Finally, he states that the spinning of the wooden surface is a visual representation of the auditory intensity of al-Bākharzì's recollection. ${ }^{78}$

74 Al-Bākharzī, Waqā’i', fol. $77 \mathrm{~b}$.

75 Al-Bākharzī, Waqā̄i', fol. 79a. Al-Bākharzī refers to al-janāb al-rafì which is a references to Kubrā who was called Abū al-Janāb.

76 Al-Bākharzī, Waqā̉ic, fol. 79b-f8oa.

77 Al-Bākharzī, Waqā̄i ${ }^{\prime}$, fol. 8oa.

78 Al-Bākharzī, Waqā̉i', fol. 8ob. 
Turning to analyse these two visions and their interpretations, it must be noted that al-Bākharzī first describes the conditions necessary for the production of visions in accordance with Kubrawi psychology. He recounts the state of seclusion and sensory deprivation, as well as the practice of recollection. Hence, the narrative in which he recounts his dream is contextualised within Kubrawi psychology and praxis. The psychological theory which outlines the connection between the soul, sensation, imagination and visions becomes part of the visionary autobiography itself here. Al-Bākharzì's visions are then interpreted by Kubrā in a manner similar to the way in which al-Baghdādī interpreted al-Balkhī's visions. The composite animal-human form of human body and bird head indicates the commanding lower soul and its blameworthy attributes, while images of celestial bodies represent the loftier faculties of the soul.

In addition to highlighting the systematic nature of Kubrawi oneirology, both texts discussed above reveal other prominent features of diagnostic dream interpretation. Firstly, the dreamer's emotional responses to his or her visions is given much attention here, hence al-Balkhī and al-Bākharzī both highlight how their visions affected them by throwing them into states of confusion, despair or depression. ${ }^{79}$ These emotional responses are then taken into account by the dream interpreter who contextualises them within the Kubrawi psychological framework where they are understood as appropriate affective responses to certain psycho-spiritual states. Moreover, Kubrawī authors pay attention to the contexts in which these visions emerged, explaining the influence of the senses, imagination and physical surroundings of the dreamer, which are at times represented in synaesthetic experiences. ${ }^{80}$

\section{Oneirology and the Institutionalisation of the Sufi Community}

Dreams and visions in medieval Muslim societies are not purely private experiences. The very act of experiencing and narrating a dream is not a solely mental or personal event. Dreams and visions occur in a cultural context which largely determines what is worth seeing and relating. ${ }^{81}$ Moreover, as a

79 Al-Bākharzī, Waqā’ $i^{\prime}$, fol. 79b.

8o For a fuller exposition of recollection, visions and synaesthesia in Kubrawī Sufism see Eyad Abuali, "Words Clothed in Light: Dhikr (Recollection), Colour and Synaesthesia in Early Kubrawī Sufism” (2019), Iran, DOI: 10.1080/o5786967.2019.1583046.

81 Shahzad Bashir, "Narrating Sight: Dreaming as Visual Training in Persianate Sufi Hagiography," In Dreams and Visions in Islamic Societies, ed. Ozgen Felek and Alexander Knysh (Albany: SUNY, 2012), 235. 
means of communication with the unseen, dreams served very public roles. By rendering the spiritual sensible, dreams reflected and shaped the medieval Muslim's understanding of his own community. Dreams and visions could highlight the blessings and charisma of the dreamer for example. ${ }^{82}$ They also allowed a person to meet with a deceased figure of authority who could convey criticism or praise of certain individuals, and in doing so, denounce or legitimate institutions. ${ }^{83}$

Dreams clearly were of interest to the wider community. If that were not the case, they would never have been related, interpreted, written down and circulated. In the cases I presented above, dreams and visions are informed by Kubrawī teachings which clearly imbue images with significant meanings through a process of interpretation which emerges as part of the visionary ritual itself. An essential part of visionary experiences for Sufi initiates was the interpretation given by the Sufi master. Hence, even these very personal and individual dream experiences are understood in a relational context between interpreter and dreamer. Furthermore, the examples of dream interpretation discussed here were clearly written down as guides for students. These private experiences are therefore given a very public life.

An important function of diagnostic dream interpretation is the creation of a collective sense of belonging between members of the Sufi community. This occurs with the incorporation of private, mental, and spiritual narratives within a shared theoretical and institutional framework, when dreams are interpreted by the Sufi master. Oneirology therefore had an important role to play in centralising communities around the Sufi master. Moreover, the psychological framework that informs Kubrawi oneirology lies at the heart of this nexus of practice, organisation, and theory. It also legitimates the spiritual authority of the Sufi master, who having achieved completion, is qualified to instruct disciples and interpret their dreams and visions. The process of dreaming or experiencing a vision, and having that experience interpreted therefore renders seemingly abstract oneiric theory a lived experience with institutional and communal significance. In fact, one of al-Baghdādī's primary arguments for the necessity of the Sufi institutional bond is the need for the Sufi aspirant to be guided by a master who should act as a safeguard against being misled by visionary experiences. ${ }^{84}$

The Sufi master therefore begins to acquire a more prominent position within the spiritual-mental life of his disciples in this period. As seen in the

82 Jonathan Katz, "Dreams and Their Interpretation in Sufi Thought and Practice," In Dreams and Visions in Islamic Societies, ed. Ozgen Felek and Alexander Knysh (Albany: SUNY, 2012), 183-4.

83 Green, "The Religious," 296.

84 Al-Baghdādī, Tuhfat al-barara, fol. 12b. 
interpretations above, both Kubrā and al-Baghdādī identified the stars with the souls of the Sufi masters. In his Fawä̀ih Kubrā states that he saw verses of the Qur'an in the form of stars in a vision of his own. ${ }^{85}$ In al-Bākharzì's writings, Kubrā goes further by equating these souls with the Qur'an itself. $\mathrm{He}$ therefore identifies a correspondence between the celestial bodies, the Qur'an, and the souls of the Sufi masters which confers onto them scriptural and cosmological authority.

The Sufi master may also literally manifest in dreams and visions without being represented symbolically. In the Tuhfa, al-Baghdādì ritualises the recollection practice of the Sufi master's name (rather than God's or the profession of faith) in order to induce a vision of the master. Al-Baghdādī explains this with reference to body-soul dualism, stating that since the soul of the shaykh is beyond temporality (ghayr mutahayyiz), it is not bound by time and space. ${ }^{86}$ As noted earlier, he also includes the Sufi master as one of the sources of thought impressions, a novel addition to the list of sources of thought impressions which appears in the Tuhfa.$^{87} \mathrm{He}$ explains that if one perceives the master in a dream or vision it is necessarily true, drawing on a prophetic tradition which states that the devil cannot impersonate the prophet in dreams, something he extends to the Sufi masters due to their likeness to prophets. ${ }^{88}$

Moreover, this psycho-spiritual connection between master and disciple carries institutional significance as al-Baghdādī reserves this right for the first and primary master of a Sufi disciple. He refers to one's first Sufi master as the master of birth-right (shaykh al-wiläda). This master stands above other subsequent masters who are referred to as masters of nurturing (shaykh altarbiya) who are described as wet-nurses and surrogates. Al-Baghdādī explains that the former are the masters from whom a Sufi may derive a spiritual lineage whereas one cannot claim lineage from the latter. ${ }^{89}$ Hence al-Baghdādī connects the visions of the Sufi master to an increasingly centralised notion of his institutional authority.

A striking example of this concordance between the idea of the Sufi master as a parent and visions of the Sufi master occurs in al-Bākharzì's Waqā̉ic In one of

85 Kubrā, Fawāih 239.

86 Al-Baghdādī, Tuhfat al-barara, fol. 28b.

87 Fritz Meier, Die Fawāịh al-Gamāl wa-Fawātih al-Galāl (Wiesbaden: Steiner, 1957), 134.

88 Al-Baghdādī, Tuhfat al-barara, fol. 28a-28b.

89 Al-Baghdādī, Tuhfat al-barara, fol. 29a-29b. 
his visions he states that he perceived his Sufi master (Kubrā) in the image of his father ${ }^{90}$ Kubrā in his interpretation explains that this vision is true since the prophet had said, "I am to you like a father is to his child", and that the scholars, or Sufi masters are like the prophets among their people. ${ }^{91}$ Both Kubrā and al-Baghdādī therefore emphasise the literal truth of perceiving one's Sufi master in a vision, and both draw on parental metaphors in this regard.

This sort of clairvoyant connection between master and disciple also served the practical purpose of maintaining institutional connections across distances. As Sufism was further institutionalised and as Sufi masters came to play more important social and political roles in medieval Islamic society, Sufis began to lead more sedentary lives. ${ }^{92}$ Whereas in the earlier period, travelling and wandering were seen as hallmarks of Sufi practice, travel came to be seen in a negative light and was restricted as communities centralised around the authority of particular masters. ${ }^{93}$ In this context spiritual and visionary travel takes precedence over physical travel. In his treatise Risāla fi al-safar, al-Baghdādī argues that the Prophetic instruction to travel and improve one's health must refer to a spiritual journey since physical travel only deteriorates one's health, as the traveller encounters unfamiliar climates. ${ }^{94}$

Furthermore, this was a period which saw political breakdown, violence and social disruption in Iran and Central Asia. The reign of the Khwarazmshahs who ruled during Kubrā and al-Baghdādī's time was marked by violence, corruption and infighting amongst the political classes. ${ }^{95}$ We know of a number of Sufis who fled Iran and Khwarazm for Anatolia in the sixth/twelfth and seventh/thirteenth centuries, the most prominent cases being that of Jalāl al-Dīn Rūmī's father, Bahā' al-Dīn Walad (d. 628/1231), as well as Najm al-Dīn al-Rāzī (d. 654/1256). ${ }^{96}$

The ability to maintain teacher-student relationships in this way mitigated the effects of social dislocation. This can be seen in the case of 'Alā' al-dawla al-Simnānī who, while barred from meeting his teacher 'Abd

\footnotetext{
$90 \quad$ Al-Bākharzī, Waqā̉ic', fol. 78a.

91 Al-Bākharzī, Waqā’i', fol. 81a.

92 Arin S. Salamah-Qudsi, "Crossing the Desert: Siyāha and Safar as Key Concepts in Early Sufi Literature and Life," Sufi Studies 2 (2013): 129-47, 147.

93 Salamah-Qudsi, "Crossing the Desert," 145-6.

94 Majd al-Dīn Al-Baghdādī, Risālāh fì al-safar, trans. Fatemeh Keshavarz in Windows on the House of Islam, ed. John Renard (Berkeley and London: University of California Press, 1998), 310.

95 Clifford Bosworth and Ali Sevim, "The Seljuqs and The Khwarazm Shahs," History of Civilization of Central Asia 4 (1999): 150-81, 181.

96 See Algar's introduction to al-Rāzì's, Mirșād, 12.
} 
al-Raḥmān al-Isfarāinī (d. 69o/129o) in Baghdad by the Ilkhanid rulers of his time, resorted to communicating with him spiritually. Hence, even an inaccessible guide could be considered sufficient for one to qualify as a disciple and legitimise an institutional bond ${ }^{97}$ The practice of performing recollection of the master in order to communicate with him seems to have survived for centuries. In later periods this practice was combined with visualising one's Sufi master and came to be known as rābiṭa in Naqshbandī Sufi circles. This was likely to have been influenced by Kubrawī Sufi practice. ${ }^{98}$ The systematisation of oneirology, and the emphasis on diagnostic dream interpretation in this period therefore had lasting implications. In addition to centralising the community around an authority who incorporates individual experiences into a shared framework of psychological and cosmological theory, this approach to dreams and visions rendered the Sufi master ever-present in the personal lives of his disciples.

\section{Conclusion}

Unlike earlier dream narratives which are unsystematic in their interpretations, these oneiric texts betray a highly sophisticated theory of dreams and visions that was made possible by the systematisation of Sufi psychology. Kubrawī oneirology marks a transition in Sufi thought regarding dreams. Focus on synaesthesia, the anatomy of the soul, as well as the dreamer's emotional responses to the experience highlights a shift towards dreams as diagnostic tools in Kubrawī Sufism. This in turn cultivated a close correspondence between the discursive, theoretical aspects of Kubrawī Sufism, the lived and personal experiences of its members, and the organisational structures of its institutions.

It seems that this trend towards diagnostic dream interpretation was not restricted to the early Kubrawiss, yet they nevertheless exemplify an important trend in the Sufism of this period. Given that the oneirology outlined here is present in almost all the works of the early Kubrawiss, and clearly influenced the works of later authors as well, it undoubtedly betrays a significant development in Sufi thought. Moreover, this oneiric theory was disseminated throughout

97 Elias, The Throne Carrier of God, 122-3.

98 Paul, Doctrine and Organisation, 36-7; 43; Shahzad Bashir, "Narrating Sight: Dreaming as Visual Training in Persianate Hagiography," In Dreams and Visions in Islamic Societies, ed. Ozgen Felek and Alexander Knysh (Albany: SUNY, 2012), 243. 
the Islamic world as Kubrawīs moved both Eastward and Westwards from Khwarazm. ${ }^{99}$

I have purposely focused on Kubrawī texts that have not received much scholarly attention. At first glance, texts such as al-Bākharzì's can seem rather strange and opaque since the visions and their interpretations are presented without much explanation of the oneiric theory which underpins them. But reading these disparate Kubrawi texts together allows us to reconstruct what is clearly a highly systematic approach to dream interpretation. Given that this is what the early Kubrawīs are famed for, it is important for their oneiric theories to be analysed in more detail.

As I have demonstrated, Kubrawī oneirology was clearly related to important socio-political changes. To what extent the development of oneiric theory was influenced by the socio-political disruptions of the sixth/twelfth and seventh/thirteenth centuries is a question which requires further research in order to be answered in full. However, what I presented here offers new insight into Sufi responses to the fractious socio-political climate of this period. The systematisation of Kubrawi oneirology strengthened the Sufi community's bond and helped it navigate some extremely tumultuous changes in the history of Iran and Central Asia.

\section{Acknowledgement}

I would like to thank Ayman Shihadeh, Dzenita Karic, Nur Sobers-Khan, Simon Leese, Adam Bursi, and Azadeh Shokouhi for all the help and advice they offered me while preparing this study.

99 Dreams and visions occupy an important place in the works of al-Simnānī and Isfarāinnī. Isfarāīnī was based in Baghdād. Najm al-Dīn al-Rāzī also moved westward before the Mongol invasions. In addition, al-Bākharzīs legacy continued in Bihar, India. See Uzma Rehman, "Firdawsiyya", in Encyclopaedia of Islam, Three, Brill Online, http://brillonline.nl/. 